Article

\title{
Do Men and Women Perceive Corruption Differently? Gender Differences in Perception of Need and Greed Corruption
}

\author{
Monika Bauhr ${ }^{1,2,3}$ and Nicholas Charron ${ }^{1, *}$ \\ ${ }^{1}$ Department of Political Science, University of Gothenburg, 41123 Gothenburg, Sweden; \\ E-Mails: monika.bauhr@pol.gu.se (M.B.), nicholas.charron@pol.gu.se (N.C.) \\ 2 QoG-Quality of Government Institute, University of Gothenburg, 41123 Gothenburg, Sweden \\ ${ }^{3}$ Center for European Studies, Harvard University, Cambridge, MA 02138, USA; E-Mail: monika_bauhr@fas.harvard.edu \\ * Corresponding author
}

Submitted: 12 December 2019 | Accepted: 12 February 2020 | Published: 28 May 2020

\begin{abstract}
Do men and women perceive corruption differently? While evidence suggest that there is a strong link between gender and corruption, and that gender differences can at least partly be derived from men and women having different attitudes towards corruption, most studies to date focus on gender differences in perceptions of the scale or severity of the corruption in general, rather than its different forms. However, we argue that factors such as role socialization, social status and life experiences may make men and women perceive different kinds of corruption. Drawing on the distinction between 'need' and 'greed' corruption, we suggest that women are more likely than men to perceive that corruption is driven by need rather than greed. In particular, women may be more likely to be exposed to need corruption because of their greater care taking responsibilities both in the professional and private sphere, and, much in line with marginalization theory, have easier access to forms of corruption that are less dependent upon embeddedness in collusive networks. Using unique survey data, we show that women and men indeed differ in their perceptions of need vs. greed, and that women perceive more need corruption, while men perceive more greed corruption. This suggests that perceptions of different forms of corruption are indeed gendered and we discuss the implication of this for anti-corruption policy.
\end{abstract}

\section{Keywords}

corruption; gender; greed; need; socialization

Issue

This article is part of the issue "Fighting Corruption in the Developed World: Dimensions, Patterns, Remedies" edited by Fabrizio Di Mascio (University of Turin, Italy) and Simona Piattoni (University of Trento, Italy).

(C) 2020 by the authors; licensee Cogitatio (Lisbon, Portugal). This article is licensed under a Creative Commons Attribution 4.0 International License (CC BY).

\section{Introduction}

In the past 20 years, studies have consistently shown a strong link between gender and corruption (Dollar, Fisman, \& Gatti, 2001; Esarey \& Schwindt-Bayer, 2018; Stensöta \& Wängnerud, 2018; Swamy, Knack, Lee, \& Azfar, 2001). Studies have shown that at least under some circumstances, increasing the share of women in elected office can lead to lower levels of corruption. Closer empirical analysis of the relationship also suggest that this relationship is neither spurious, i.e., solely driven by other factors such as the develop- ment of liberal democracy, or simply attributable to reversed causality (Bauhr \& Charron, 2020; Brollo \& Troiano, 2016; Correa Martinez \& Jetter, 2016; Esarey \& Schwindt-Bayer, 2019; Jha \& Sarangi, 2018). Thus, while low corrupt and less patronage-based recruitment systems may indeed facilitate the recruitment of women into office (Bjarnegård, 2013; Stockemer \& Sundström 2019; Sundström \& Wängnerud, 2016), evidence also suggest that women can make a difference once in office. Within this research field, there are studies that have shown gender differences in how citizens experience, tolerate and perceive corruption on whole (Bauhr, 
Charron, \& Wängnerud, 2019; Melgar, Rossi, \& Smith, 2010; Swamy et al., 2001). Theoretical frameworks seeking to explain this effect draw on both macro- and micro-level theories on gender differences, to argue that there are indeed systematic differences in how men and women perceive corruption (Alexander, in press).

This study draws on this emerging body of work to investigate systematic differences in public perceptions of corruption between men and women. However, it is common in much of the empirical corruption literature to not systematically distinguish and account for the vast variation between different forms of corruption (see Bauhr et al., 2019, for an exception). When investigating the link between gender and corruption this may be particularly consequential, since differences in role socialization, social status and experiences may make men and women perceive not only differences in the scale or importance of the corruption problems, but also make men and women perceive different types of corruption.

Specifically, we build on the distinction between 'need' and 'greed' corruption (Bauhr, 2017) and suggest that women are more likely than men to perceive that corruption is driven by need and that men are more likely to perceive that corruption is driven by greed. Following Bauhr (2017) we define need corruption as corruption needed to gain access to public services and avoid transgression of government power, and greed corruption as corruption used to gain access to special illicit advantages, unfair privileges and wealth. We also draw on socialization and marginalization theories to propose two potential explanations for the differences found. Gender differences in socialization into caretaking roles and professions may explain differences in perceptions of the prevalence of need corruption, furthermore, much in line with marginalization theories (for example, Barnes \& Beaulieu, 2018; Bjarnegard, 2013; Goetz, 2007; Heath, Schwindt-Bayer, \& Taylor-Robinson, 2005), women are less likely to be included in the collusive insider networks (which are often male-dominated) that facilitate greed based transactions, and will thereby be less likely to perceive this form of corruption as prevalent.

Our analysis uses the third round of the European Quality of Government Index survey (Charron, Lapuente, \& Annoni, 2019), and data from 77,966 respondents in 185 European regions. Within the survey, we employ unique questions capturing the need vs. greed forms of corruption, and we show that women perceive higher need corruption on average, while men tend to perceive a higher level of greed corruption.

We thereby seek to make several interrelated contributions. To the best of our knowledge, this study is the first that systematically investigates gender differences in the perceived prevalence of different forms of corruption, and in particular differences between need and greed corruption. Several studies suggest that women, on average, are less tolerant towards corruption (Alexander, Bågenholm, \& Charron, 2019; Swamy et al., 2001). Most studies to date, however, investigate either the macro-level association between women representation and lower levels of corruption (Dollar et al., 2001), or micro-level differences between men and women's levels of tolerance towards corruption, whether expressed through vote choice (Alexander et al., 2019), perceptions of the extent to which corruption is justifiable (Swamy et al., 2001) or the varying propensity of men and women to engage in corruption (Bauhr et al., 2019). This study builds on new data specifically designed to measure the distinction between need and greed corruption and a large sample of respondents to investigate how the perceived nature of the corruption problem differs among men and women. In doing so, we add to the rich literature that seeks to explain the gender and corruption nexus to suggest that two factors in particular may drive gender differences in the perceived prevalence of these different forms of corruption. We highlight women socialization into greater care taking obligation, both in the private and public sphere and power marginalization (Bjarnegård, 2013; Schwindt-Bayer, 2010) that tend to exclude women's access to greed to a greater extent than need corruption.

The study thereby adds to a closer understanding of the link between gender and corruption, by showing that the perceived nature of the corruption problem differs between men and women. An important challenge for current anticorruption efforts is the vastly different nature of different forms of corruption; differences which tend to be ignored in studies that employ the widelyused, aggregate measures, such as the World Bank's Control of Corruption, or Transparency International's Corruption Perceptions Index. Specifically, anticorruption interventions may not have an equal effect across different forms of corruption, and such interventions may thereby need to be tailored to the type of corruption problem that they seek to address. Investigating public perceptions of different forms of corruption, and how it varies across societies and groups, is therefore an important first step in understanding public demand for different types of anticorruption reforms.

\section{Gender and Corruption}

There is a growing literature that investigates gender differences in attitudes toward corruption. Using World Value Survey data, Swamy et al. (2001) investigate respondents' answers regarding hypothetical scenarios involving dishonest and opportunistic behavior, such as cheating on taxes or avoiding a fare on public transport. They found that women were more likely than men to respond that dishonest or illegal behavior was 'never justifiable.' These gender differences were also found when investigating attitudes towards corruption in general, where women were found to be less likely to condone corruption compared to men. Although findings on whether men or women are more likely to value honest behavior and legal norms in general are somewhat mixed, several studies confirm that women 
show a stronger aversion towards corruption than men (see Hernandez \& McGee, 2012; Torgler \& Valev, 2010). Relatedly, evidence also suggests that women are more likely to mobilize against corruption. Recent studies investigate gender differences in voter responses to corruption and find that women are more likely to refrain from voting for a party and candidate involved in corruption (Alexander et al., 2019).

Additionally, studies consistently show a strong association between women representation and lower levels of corruption (Bauhr et al., 2019; Dollar et al., 2001; Esarey \& Schwindt-Bayer, 2018; Stensöta \& Wängnerud, 2018; Swamy et al., 2001). Several possible explanations have been suggested for this link. Some studies attribute this difference to women on average being more pro social than men, and thereby more likely to engage in "helping' behavior, which also explains their greater propensity to base voting decisions on social concerns (Eagly \& Crowley, 1986; Goertzel, 1983). Building on studies from different disciplines, including criminology, risk sociology and political psychology (Bord \& O'Connor, 1997; Watson \& McNaughton, 2007), scholars have directed particular attention to the notion of women being more risk averse than men (Esarey \& Schwindt-Bayer, 2018; Swamy et al., 2001). Relatedly, studies suggest that citizens expect women in office to be less corrupt than men (Barnes \& Beaulieu, 2014, 2018); and they may therefore also be more severely punished for engaging in corruption by the electorate, which increases the de facto risk of participating in corruption. However, the literature on whether or not voters treat women and men differently at the polls has produced somewhat mixed results (see, e.g., Eggers, Vivyan, \& Wagner, 2018; Żemojtel-Piotrowska, Marganski, Baran, \& Piotrowski, 2016) Furthermore, a growing body of experimental work suggest that women engage less in corruption than men (for a review of this literature see Chaudhuri, 2012). For example, Fišar, Kubák, Špalek, and Tremewan (2016) assert that "women are less likely to engage in punishment of corruption and believe corruption to be more prevalent than men." However, evidence also suggests that gender differences are context dependent, since they are stronger in more advanced economies (Alatas, Cameron, Chaudhuri, Erkal, \& Gangadharan, 2009), in democracies (Esarey \& Schwindt-Bayer, 2018) and in the legislative arena (Stensöta, Wängnerud, \& Svensson, 2015).

Most studies to date, however, investigate either the macro-level association between women representation and lower levels of corruption, or micro-level differences between men and women's levels of tolerance towards corruption, whether expressed through vote choice, perceptions of the extent to which corruption is justifiable or the varying propensity of men and women to engage in corruption. Studies have also developed a number of plausible theories about why women would be less likely to engage in corruption or more likely to mobilize against it. These including theories of women being socialized into being more pro social, norm compli- ant or risk averse than men. In addition, that women may be more dependent on a well-functioning state because of their greater care taking obligations (Alexander \& Ravlik, 2015; see also Jha \& Sarangi, 2018; Neudorfer, 2016). For example, several studies suggest that women are more likely to prioritize the improvement of public service delivery as elected officials, and in particular in sectors that benefit women (Bolzendahl, 2009; Dolan, 2010; Ennser-Jedenastik, 2017; Jha \& Sarangi, 2018; Schwindt-Bayer \& Mishler, 2005; Smith, 2014). Others assert that women are simply marginalized and excluded from participating in corrupt transactions (Barnes, 2016; Bjarnegård, 2013; Goetz, 2007; Heath et al., 2005; Schwindt-Bayer, 2010).

None of the studies we are aware of, however, investigates whether there are gender differences in the perceived prevalence of different forms of corruption. Thus, while previous research highlights several reasons why men and women may experience corruption differently and thereby develop different attitudes towards corruption, most studies to date use either aggregate indices of corruption levels or the more specific example of bribe paying. However, failing to recognize the sometimes-large variations between different forms of corruption (Bauhr, 2017), and that perceptions of different forms of corruption may vary across different segments of the population, limits our understanding of both citizens' attitudes towards corruption and drivers of anticorruption mobilization. The ensuing section develops our theoretical contribution and elucidates our empirical hypothesis.

\section{Gender Differences in Perceptions of Different Forms of Corruption}

An important challenge for anticorruption efforts is the vastly different nature of different forms of corruption. While several scholars note the importance of disaggregating the concept of corruption in order to understand the effectiveness of anticorruption reforms (Bauhr, 2017; Heywood, 2017), such disaggregation is more often made in theoretical accounts than in empirical research. For long, comparative corruption research has been dominated by the use of aggregate indices of corruption capturing how much corruption there is any particular polity rather than its different forms (e.g., Ades \& Di Tella, 1997; Fisman \& Gatti, 2002; Mauro, 1995; Treisman, 2007). Subsequent analyses have made important attempts to distinguish between different forms of corruption based on, for example, the size and scale (e.g., petty vs. grand corruption), or relational distinctions (extortive vs. collusive corruption). Others mention the motivations for engaging in corruption (need vs. greed), the perceived normality of corruption (such as Heidenheimer \& Johnston, 2002, referring to white, grey, or black corruption) and distinctions between different forms of favoritism (nepotism, cronyism, clientelism). Despite these conceptual nuances, our under- 
standing of gender differences in perceptions of different forms of corruption remain scant.

This study investigates gender differences in perceptions of two forms of corruption where we expect such differences to be prevalent: need and greed corruption (Bauhr, 2017). This distinction focuses on the basic motivation for engaging in corruption. Individuals engage in need corruption if it is the only way to receive services or avoid abuses of power and in greed corruption to receive special illicit advantages, privileges and wealth. The differences could be thought of as the difference between using corruption if it is the only way to secure health care for yourself or your dependents and using corruption to gain a public contract without having the most competitive bid.

At least two important theoretical approaches to the link between gender and corruption could contribute towards explaining gender differences in the perceived prevalence of need and greed corruption. First, theoretical expectations derived from socialization theories, and in particular women's socialization into greater care taking responsibilities may explain the higher levels of perceive prevalence of need corruption. Gender role socialization makes women on average assume greater care taking responsibility for family, including children and elderly (Eagly \& Wood, 2016). These caretaking obligations may also lead to encounters of need corruption in sectors such as schools and health care. Furthermore, gender role socialization has also been shown to influence career choices and employment (Eagly \& Wood, 2016). Women may therefore also be more likely to perceive or define corruption as need corruption in their professional roles as teachers, doctors or health workers, professions that also typically entail a comparatively high level of street level discretion, and tend to be in the public sector.

Second, studies suggest that women are not only more pro social, care oriented and risk averse; they are also more likely to be excluded from certain forms of corrupt transactions. In particular, marginalization theories suggest that women lack opportunities to participate in certain forms of corrupt transactions, in particular the forms of corruption that are secretive, collusive and dependent upon embeddedness in 'old boys networks.' Several studies suggest that women are more likely to be excluded from such tightly knit networks, and therefore have less opportunities to engage in corruption (Barnes, 2016; Barnes \& Beaulieu, 2018; Bjarnegård, 2013; Escobar-Lemmon \& Taylor-Robinson, 2009; Heath et al., 2005; Schwindt-Bayer, 2010). This suggest that women may be particularly unlikely to experience or observe greed corruption, since they may simply be excluded from participating in it. Thus, while insiders benefit from corruption in contexts where corruption in prevalent and therefore perpetuate it (Bauhr \& Charron, 2018), greed corruption oftentimes remains secretive and unseen by outsiders, which may explain why women are less likely to perceive greed corruption as prevalent. Taken together, as our hypothesis, we expect that women would perceive need corruption as more prevalent, while men would perceive a higher prevalence of greed corruption:

$\mathrm{H}$ : Women perceive a higher prevalence of need corruption, while men perceive a higher prevalence of greed corruption.

\section{Sample, Data and Design}

This study relies on newly collected data from the third round of the Quality of Government Institute's European Quality of Government Index survey (Charron et al., 2019). The survey's primary aim is to build regional indices of quality of government and facilitate multi-level research on governance in the EU countries (Charron, Dijkstra, \& Lapuente, 2015). The questions capture the extent to which citizens experience and perceive corruption within their local and regional public services and feel that their services are of good quality, are treated fairly by local public servants and that services are allocated impartiality to all citizens. The sample is made up of residents of 18 years of age or older, who were contacted randomly via telephone in the local language. Telephone interviews were conducted via both landlines and mobile phones, with both methods of administration being applied in most countries. In all, 77,966 respondents were included in $21 \mathrm{EU}$ countries and the survey design selected respondents within 185 regions in these countries, such that design weights are used in all analyses to account for this (see the Supplementary File, Appendix II, for more details on the survey).

The survey includes several questions on perceptions of corruption that are of interest here and serve as dependent variables in the analyses. The two most suitable questions to test our theory, developed by the authors of this study, are those that pertain to various types of general, societal corruption which seek to make the distinction between 'need' and 'greed' corruption respectively (Bauhr, 2017).

Need corruption is measured by the statement 'People in my area must use some form of corruption just to get some basic public services'; greed corruption is measured by the statement: 'Corruption in my area is used to get access to special unfair privileges and wealth.'

Respondents are asked to agree with these statements on a scale of $1-10$, in which 10 is full agreement and 1 is full disagreement. Figure 1 shows the distribution of these two main variables via a scatterplot, in which we observe that corruption is perceived as lowest in Denmark and the highest Croatia, and the difference between high and low country is roughly two standard deviations in the corruption variables, suggesting vast country level variation overall. The data show that greed corruption is perceived as higher in all countries (save Romania), while in some countries-such as Czech Republic and Hungary, greed corruption is perceived as considerably higher than need corruption. 


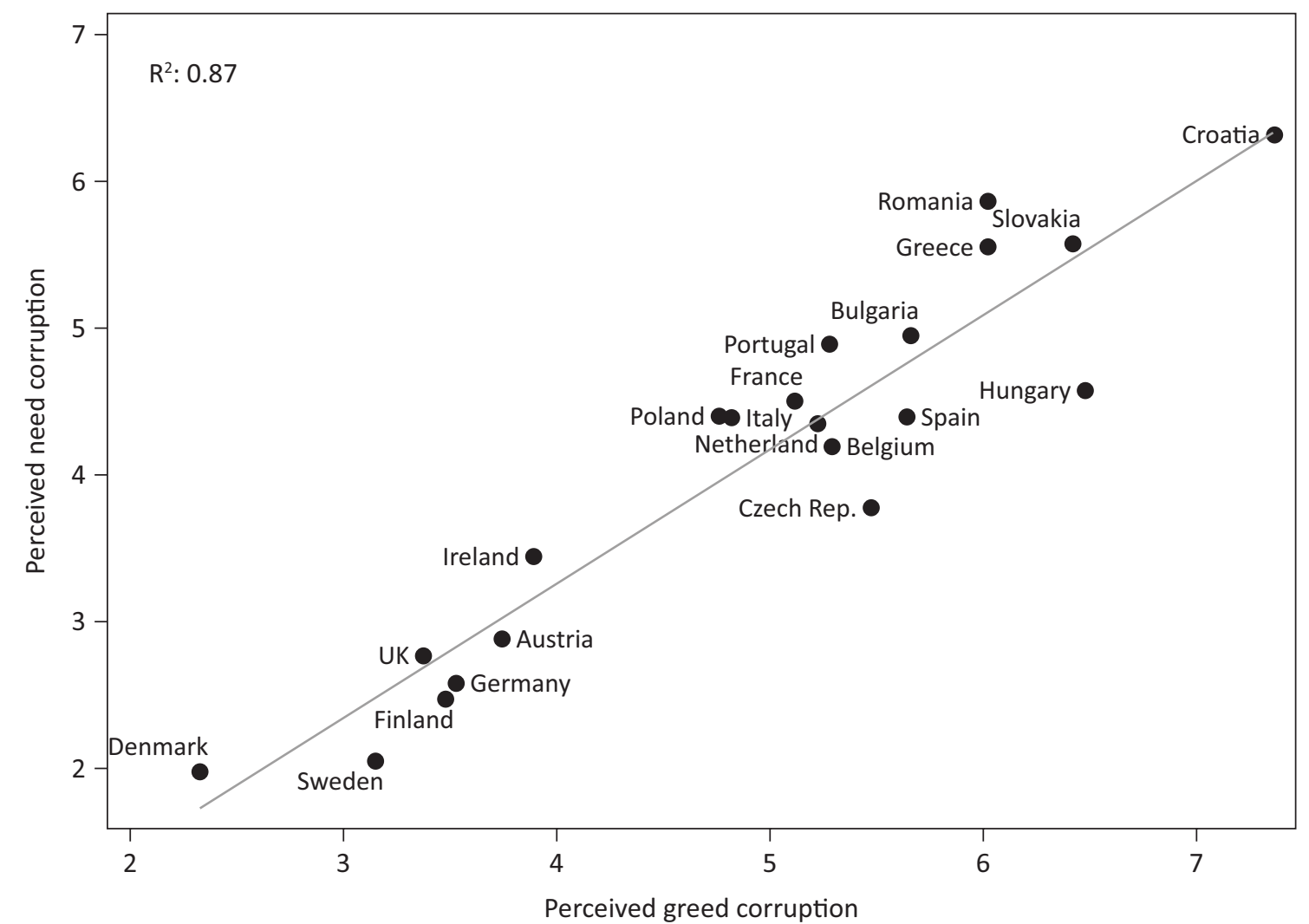

Figure 1. Citizen perceptions corruption in $21 \mathrm{EU}$ countries. Note: Weighted country means reported.

The main independent variable of interest is the gender of the respondent, coded as binary $(1=$ female, $0=$ male). We attempt to account for several factors, which could confound the relationship between gender and corruption perceptions by including a number of control variables. First, at the individual level, we account for education. While the effects of higher education on corruption perceptions is somewhat mixed with samples outside the EU (Donchev \& Ujhelyi, 2014; Razafindrakoto \& Roubaud, 2010), studies in Europe have shown higher education is associated with lower perception (Charron, 2016). As the rate of women in higher education varies by country, we include a dummy for university education or higher to account for this. Second, we account for political values representing left-right dimension, which could confound the main relationships, in particular at the extreme ends (Charron \& Bågenholm, 2016). These are accounted for with questions pertaining for example to preferences for income redistribution included in the 2017 survey (see the Supplementary File, Appendix II). As several factors could be proxies for corruption perceptions, we also control for support for the sitting government party (or party in a government collation), and one's satisfaction with the current economy, all of which have been shown to be inter-related (Manzetti \& Wilson, 2006). In our sample, women are significantly less likely to profess support for a sitting government party and they tend to rate the current economy more negatively than men on average thus we control for party support to account for this potentially confounding effect.
Next, we account for workforce sector (private, public or non-working), as public sector workers, who tend to be women more on average in many countries, tend to perceive lower corruption on average (Charron, 2016). Finally, at the individual level, we control for one's personal experience with petty corruption, as women have significantly lower rates of self-reported experience in our sample and in other studies of petty corruption (see Justesen \& Bjørnskov, 2014), thus we control for this potentially confounding effect.

As the individuals in our sample are nested in larger regional and country contexts, we account for this with several macro-level variables. First, we include countrylevel fixed effects to control for unobserved, countrylevel variation, which could bias our estimates. Second, we include measures of institutional quality from the European Quality of Government Index (Charron et al., 2015), which measure the level of perceived and experienced corruption in local services and the degree to which citizens believe that services are allocated impartially and with high quality. Given we find significant within-country variation in institutional quality; we expect that this will be a strong negative predictor of corruption perceptions. Third, we include a measure for the proportion of women MPs in local parliaments from Sundström (2013), which could serve as a heuristic for citizens, in particular women, that there is less influence from 'good old boy clubs.'

As our dependent variables are coded 1-10, we rely mainly on least squares regression, although we check in 
addition for the results via ordered logit. All models include survey design weights and robust standard errors, clustered on countries.

\section{Empirical Results}

We begin with looking at the relationship between gender and need corruption perceptions in Table 1 . The first model includes only gender and country fixed effects, while the second includes the micro-level controls and the third model adds the regional level items. Model 1 shows that women on average tend to perceive higher levels of need corruption compared with men. The marginal effect is reduced by roughly one-half with the inclusion of the controls, suggesting confounding effects by some of the control variables, but the relationship-while relatively small-is significant at the 0.05 level of confidence.
Table 2 investigates the relationship between gender and greed corruption perceptions. We approach this outcome similarly to Table 1 , by adding control variables to test for nested models. In contrast to need corruption, women perceive significantly lower levels of greed corruption throughout the three models. Moreover, the effects become over $70 \%$ greater when adding individual and regional level controls as compared with model 1 , and the effects are significant at the 0.01 level of confidence. This implies that when accounting for factors such as education, age and occupational sector for example, that the gap in perceptions between males and females is in fact larger among respondents who are more demographically similar and share similar attitudes on redistributive politics and the economy on whole.

As noted, our control variables predict both types of corruption perceptions in rather similar ways, although there is some variation in the magnitude of effects.

Table 1. Estimates for need corruption.

\begin{tabular}{|c|c|c|c|}
\hline & $\begin{array}{l}\text { (1) } \\
\text { Baseline }\end{array}$ & $\begin{array}{c}(2) \\
\text { Add micro controls }\end{array}$ & Add micro \& regional controls \\
\hline Female & $\begin{array}{l}0.098 * * * \\
(0.024)\end{array}$ & $\begin{array}{l}0.046^{* *} \\
(0.023)\end{array}$ & $\begin{array}{l}0.048^{* *} \\
(0.023)\end{array}$ \\
\hline Education & & $\begin{array}{l}-0.441 * * * \\
(0.025)\end{array}$ & $\begin{array}{l}-0.443 * * * \\
(0.026)\end{array}$ \\
\hline Age & & $\begin{array}{l}-0.003 \\
(0.013)\end{array}$ & $\begin{array}{c}-0.003 \\
(0.013)\end{array}$ \\
\hline Corruption experience & & $\begin{array}{l}0.444^{* * *} \\
(0.018)\end{array}$ & $\begin{array}{l}0.436 * * * \\
(0.018)\end{array}$ \\
\hline Economic satisfaction: very good & & $\begin{array}{l}-1.279 * * * \\
(0.061)\end{array}$ & $\begin{array}{l}-1.271^{* * *} \\
(0.061)\end{array}$ \\
\hline Economic satisfaction: somewhat good & & $\begin{array}{l}-0.984 * * * \\
(0.046)\end{array}$ & $\begin{array}{l}-0.982 * * * \\
(0.047)\end{array}$ \\
\hline Economic satisfaction: somewhat bad & & $\begin{array}{l}-0.429 * * * \\
(0.044)\end{array}$ & $\begin{array}{l}-0.439 * * * \\
(0.046)\end{array}$ \\
\hline Private sector & & $\begin{array}{l}-0.015 \\
(0.030)\end{array}$ & $\begin{array}{l}-0.007 \\
(0.030)\end{array}$ \\
\hline Public sector & & $\begin{array}{l}-0.295^{* * *} \\
(0.034)\end{array}$ & $\begin{array}{l}-0.291^{* * *} \\
(0.035)\end{array}$ \\
\hline Support government party & & $\begin{array}{l}-0.117^{* * *} \\
(0.027)\end{array}$ & $\begin{array}{l}-0.117 * * * \\
(0.027)\end{array}$ \\
\hline Support redistribution & & $\begin{array}{l}-0.676 * * * \\
(0.046)\end{array}$ & $\begin{array}{l}-0.658 * * * \\
(0.046)\end{array}$ \\
\hline European Quality of Government Index (2013) & & & $\begin{array}{l}-0.330 * * * \\
(0.035)\end{array}$ \\
\hline$\%$ women in Parliament & & & $\begin{array}{l}-0.018^{* * *} \\
(0.003)\end{array}$ \\
\hline Country fixed effects & $\sqrt{ }$ & $\sqrt{ }$ & $\sqrt{ }$ \\
\hline Constant & $\begin{array}{l}4.220 * * * \\
(0.039)\end{array}$ & $\begin{array}{l}5.218^{* * * *} \\
(0.069)\end{array}$ & $\begin{array}{l}6.048^{* * * *} \\
(0.122)\end{array}$ \\
\hline Obs. & 77966 & 77612 & 74718 \\
\hline R-squared & 0.130 & 0.166 & 0.167 \\
\hline
\end{tabular}

Notes: Dependent variable is perceptions of 'need' corruption, with higher values implying higher perceived corruption. Robust standard errors in parentheses from linear regression. Country fixed effects included in all models (not shown). Reference to economic satisfaction is 'very bad,' reference to labor force sector is 'not currently working.' ${ }^{* * *} \mathrm{p}<0.01, * * \mathrm{p}<0.05,{ }^{*} \mathrm{p}<0.1$. 
Table 2. Estimates for greed corruption.

\begin{tabular}{|c|c|c|c|}
\hline & $\begin{array}{l}(1) \\
\text { Baseline }\end{array}$ & $\begin{array}{c}(2) \\
\text { Add micro controls }\end{array}$ & Add micro \& regional controls \\
\hline Female & $\begin{array}{l}-0.058 * * \\
(0.025)\end{array}$ & $\begin{array}{l}-0.097^{* * *} \\
(0.025)\end{array}$ & $\begin{array}{l}-0.10 * * * \\
(0.025)\end{array}$ \\
\hline Education & & $\begin{array}{l}-0.156 * * * \\
(0.027)\end{array}$ & $\begin{array}{c}-0.167 * * * \\
(0.027)\end{array}$ \\
\hline Age & & $\begin{array}{l}-0.052 * * * \\
(0.013)\end{array}$ & $\begin{array}{l}-0.054^{* * *} \\
(0.014)\end{array}$ \\
\hline Corruption experience & & $\begin{array}{l}0.451^{* * *} \\
(0.018)\end{array}$ & $\begin{array}{l}0.442^{* * *} \\
(0.018)\end{array}$ \\
\hline Economic satisfaction: very good & & $\begin{array}{l}-1.319 * * * \\
(0.064)\end{array}$ & $\begin{array}{l}-1.301^{* * *} \\
(0.065)\end{array}$ \\
\hline Economic satisfaction: somewhat good & & $\begin{array}{l}-1.006 * * * \\
(0.046)\end{array}$ & $\begin{array}{l}-0.992^{* * *} \\
(0.047)\end{array}$ \\
\hline Economic satisfaction: somewhat bad & & $\begin{array}{l}-0.386 * * * \\
(0.044)\end{array}$ & $\begin{array}{l}-0.386 * * * \\
(0.045)\end{array}$ \\
\hline Private sector & & $\begin{array}{l}0.153^{* * *} \\
(0.031)\end{array}$ & $\begin{array}{l}0.156^{* * *} \\
(0.031)\end{array}$ \\
\hline Public sector & & $\begin{array}{l}-0.222 * * * \\
(0.036)\end{array}$ & $\begin{array}{l}-0.227^{* * *} \\
(0.037)\end{array}$ \\
\hline Support government party & & $\begin{array}{l}-0.242^{* * *} \\
(0.029)\end{array}$ & $\begin{array}{l}-0.242 * * * \\
(0.029)\end{array}$ \\
\hline Support redistribution & & $\begin{array}{l}-0.921 * * * \\
(0.049)\end{array}$ & $\begin{array}{l}-0.900 * * * \\
(0.049)\end{array}$ \\
\hline European Quality of Government Index (2013) & & & $\begin{array}{l}-0.390 * * * \\
(0.036)\end{array}$ \\
\hline$\%$ women in Parliament & & & $\begin{array}{c}-0.005 \\
(0.003)\end{array}$ \\
\hline Country fixed effects & $\sqrt{ }$ & $\sqrt{ }$ & $\sqrt{ }$ \\
\hline Constant & $\begin{array}{l}4.975 * * * \\
(0.040)\end{array}$ & $\begin{array}{l}6.003^{* * *} \\
(0.070)\end{array}$ & $\begin{array}{l}6.399 * * * \\
(0.127)\end{array}$ \\
\hline Obs. & 77966 & 77612 & 74718 \\
\hline R-squared & 0.122 & 0.159 & 0.156 \\
\hline
\end{tabular}

Notes: Dependent variable is perceptions of 'need' corruption, with higher values implying higher perceived corruption. Robust standard errors in parentheses from linear regression. Country fixed effects included in all models (not shown). Reference to economic satisfaction is 'very bad,' reference to labor force sector is 'not currently working.' *** $p<0.01, * * p<0.05,{ }^{*} p<0.1$.

Education is associated with lower levels of corruption perceptions, consistent with most previous empirical studies (Donchev \& Ujhelyi, 2014; Truex, 2011). Age is a negative predictor, yet only significant for greed corruption. Not surprisingly, personal experience with petty corruption drives higher perceptions of both need and greed corruption, which is consistent with several previous studies (Charron, 2016; Donchev \& Ujhelyi, 2014) while positive views of the economy are associated with lower perceptions. Supporters of a sitting government party also have lower perceptions on average, which is consistent with previous findings (Tverdova, 2011), as do people with more left-leaning attitudes on government redistribution, all things being equal, which contributes to the mixed findings on whether left- or rightleaning ideology yields higher corruption perceptions (Curini, 2017; Holmberg, 2009). Compared with people who are unemployed, public sector workers tend to perceive lower corruption, while private sector workers tend to perceive higher levels. Both regional level variables predict corruption perceptions in the expected direction, yet women in parliament is only significant for need corruption, while past level of institutional quality in one's region positively predicts both types of corruption perceptions. Interestingly, when comparing the effects of the variables across the two model for need and greed corruption, the gender variable is the only variable that changes sign, as all other variables show a more or less consistent effect on both types of corruption perceptions.

Figure 2 summarizes the main findings of the study, showing the marginal effects of gender (female) respondents across the six models reported.

Finally, as the socialization mechanism of our theory implies that the effect of gender could be mediated by career choice, we attempt to test this effect through mul- 


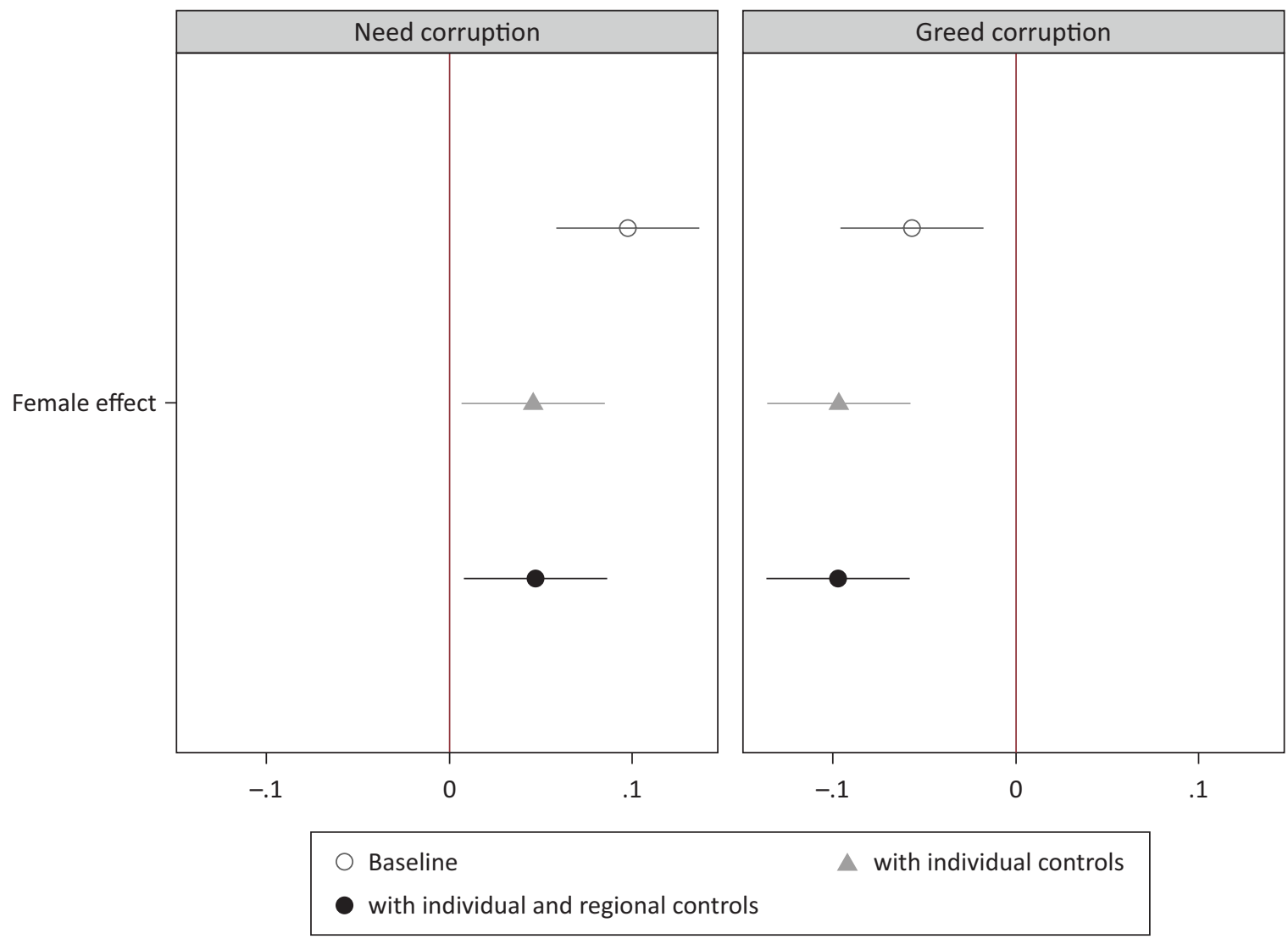

Figure 2. Summary of main effects. Note: Point estimates show marginal effects of female (compared with males) on the two perceptions of corruption with $95 \%$ confidence intervals.

tilevel mediation analysis to test the degree to which our gender effects are actually mediated through occupation. In these analyses, we tested the mediation effect of gender with an (admittedly broad) measure of public/private sector employment, in that women tend to work in the private sector at systematically lower rates than men and that private sector employees tend to have higher perceptions of corruption than do unemployed or public sector workers (see Table 2). We find that our main reported effects are in large part quite consistent with the mediation-some $25 \%$ and $28 \%$ of the total gender effects that we find for need and greed corruption are via occupation (see the Supplementary File, Appendix 3 and Table A3, for full results). While we do not rule out other mediation channels, we find that such evidence does suggest both strong direct effects and some significant indirect effects of gender on perceptions of corruption via occupational socialization mechanisms, which provides some evidence for the mechanisms proposed in part of our theory.

\section{Discussion}

This study investigates gender differences in the perceived prevalence of different form of corruption. Specifically, we investigate perceptions of two types of corruption-need and greed-and suggest that female respondents should have higher perceptions of need cor- ruption, while lower perceptions of greed corruption compared with male respondents on average. Using a large sample survey of nearly 80,000 respondents in $21 \mathrm{EU}$ countries, we find empirical support for this claim.

The argument we make builds on gendered theories of care taking and power marginalization. On the one hand, women are socialized into care taking roles, which implies a greater deal of time invested in activities such as education and health care, which in turn have implications for occupational choices (Eagly \& Wood, 2016). In these areas, at times even in some parts of Europe, some degree of need corruption is warranted to obtain services. That women are more involved on average in these services implies that their perception of such need corruption should be higher, which we in fact observe. On the other hand, marginalization theory suggests that women are on average, often excluded from positions and decision-making areas where greed corruption is likely to take place. We thus expected women's perception of this type of corruption to be in fact lower than male perceptions, for which we find robust empirical support. Interestingly, among the many correlates included in the model, gender was the only variable in which we found this distinction between need and greed corruption.

This study shows the salience of distinguishing between types of corruption as well as keeping in mind gender differences when considering aggregate levels of cor- 
ruption based on survey data. To the best of our knowledge, this is the first study that investigates gender differences in perceptions of different forms of corruption and in particular, need and greed corruption. It is important to note that although our theory posits two mechanisms, our study does not explicitly investigate why we find gender difference in perceptions of different forms of corruption. However, the mediation analysis we perform does suggest some of the effect of gender on corruption perceptions is channeled via occupation, which implies some evidence for the socialization mechanism. Although our results are consistent with the predicted observable implications of the theoretical framework we suggest, explicitly investigating why these differences occur is a viable and interesting avenue for future research. Gaining a closer understanding of gender differences in perceptions of different forms of corruption may hold the key to a closer understanding of how and why demand for anticorruption reforms differ across different segments of a population. Thus, gender differences in perceptions of different forms of corruption does not only reflect differences in roles and experiences of different societal groups, it may ultimately shape public support for anticorruption reforms.

\section{Acknowledgments}

Nicholas Charron is grateful for financial support from European Commission's Directorate General for Regional Policy (DG Regio), Grant/Award Number: 2016.CE. 16.BAT.06; and Monika Bauhr would like to acknowledge institutional support from the Center for European Studies, Harvard University, USA, the Swedish Foundation for Humanities and Social Sciences (GSAB19-042), The Wenner-Gren Foundation and the Swedish Research Council, (2019-02636).

\section{Conflict of Interests}

The authors declare no conflict of interests.

\section{Supplementary File}

Supplementary material for this article is available online in the format provided by the authors (unedited).

\section{References}

Ades, A., \& Di Tella, R. (1997). The new economics of corruption: A survey and some new results. Political Studies, 45(3), 496-515.

Alatas, V., Cameron, L., Chaudhuri, A., Erkal, N., \& Gangadharan, L. (2009). Gender, culture, and corruption: Insights from an experimental analysis. Southern Economic Journal, 75(3), 663-680.

Alexander, A. C. (in press). Gender, gender equality and corruption: A review of theory and evidence. In A. Bagenholm, M. Bauhr, M. Grimes, \& B. Rothstein
(Eds.), Oxford handbook of quality of government. Oxford: Oxford University Press.

Alexander, A. C., Bågenholm, A., \& Charron, N. (2019). Are women more likely to throw the rascals out? The mobilizing effect of social service spending on female voters. Public Choice, 1-27. https://doi.org/10.1007/ s11127-019-00761-w

Alexander, A. C., \& Ravlik, M. (2015). Responsiveness to women's interests as a quality of government mechanism: A global analysis of women's presence in national legislatures and anti-trafficking enforcement. Paper presented at the American Political Science Association's Annual Meeting, San Francisco, CA.

Barnes, T. (2016). Gendering legislative behavior: Institutional constraints and collaboration. New York, NY: Cambridge University Press.

Barnes, T. D., \& Beaulieu, E. (2014). Gender stereotypes and corruption: How candidates affect perceptions of election fraud. Politics \& Gender, 10(3), 365-391.

Barnes, T. D., \& Beaulieu, E. (2018). Women politicians, institutions, and perceptions of corruption. Comparative Political Studies, 52(1), 134-167.

Bauhr, M. (2017). Need or greed? Conditions for collective action against corruption. Governance, 30(4), 561-581.

Bauhr, M., \& Charron, N. (2018). Insider or outsider? Grand corruption and electoral accountability. Comparative Political Studies, 51(4), 415-446.

Bauhr, M., \& Charron, N. (2020). Will women executives reduce corruption? Marginalization and network inclusion. Manuscript submitted for publication.

Bauhr, M., Charron, N., \& Wängnerud, L. (2019). Exclusion or interests? Why females in elected office reduce petty and grand corruption. European Journal of Political Research, 58(4), 1043-1065.

Bjarnegård, E. (2013). Gender, informal institutions and political recruitment: Explaining male dominance in parliamentary representation. New York, NY: Palgrave Macmillan.

Bolzendahl, C. (2009). Making the implicit explicit: Gender influences on social spending in twelve industrialized democracies, 1980-99. Social Politics, 16(1), 40-81.

Bord, R., \& O'Connor, R. (1997). The gender gap in environmental attitudes: The case of perceived vulnerability to risk. Social Science Quarterly, 78(4), 830-840.

Brollo, F., \& Troiano, U. (2016). What happens when a woman wins an election? Evidence from close races in Brazil. Journal of Development Economics, 122, 28-45.

Charron, N. (2016). Do corruption measures have a perception problem? Assessing the relationship between experiences and perceptions of corruption among citizens and experts. European Political Science Review, 8(1), 147-171.

Charron, N., \& Bågenholm, A. (2016). Ideology, party systems and corruption voting in European democracies. Electoral Studies, 41, 35-49.

Charron, N., Dijkstra, L., \& Lapuente, V. (2015). Mapping 
the regional divide in Europe: A measure for assessing quality of government in 206 European regions. Social Indicators Research, 122(2), 315-346.

Charron, N., Lapuente, V., \& Annoni, P. (2019). Measuring quality of government in EU regions across space and time. Papers in Regional Science, 98(5), 1925-1953.

Chaudhuri, A. (2012). Gender and corruption: A survey of the experimental evidence. In D. A. Norton, D. Serra, L. Wantchekon, \& R. M. Isaac (Eds.), New advances in experimental research on corruption (pp. 13-49). Bingley: Emerald Group Publishing Limited.

Correa Martinez, W., \& Jetter, M. (2016). Isolating causality between gender and corruption: An IV approach (Working Paper No. 16-07). Paris: Center for Research in Economics and Finance. Retrieved from https://ssrn.com/abstract=2756794

Curini, L. (2017). Corruption, ideology, and populism: The rise of valence political campaigning. Cham: Springer Publishing.

Dolan, K. (2010). The impact of gender stereotyped evaluations on support for women candidates. Political Behavior, 32(1), 69-88.

Dollar, D., Fisman, R., \& Gatti, R. (2001). Are women really the "fairer" sex? Corruption and women in government. Journal of Economic Behavior \& Organization, 46(4), 423-429.

Donchev, D., \& Ujhelyi, G. (2014). What do corruption indices measure? Economics \& Politics, 26(2), 309-331.

Eagly, A. H., \& Crowley, H. (1986). Gender and helping behaviour: A meta-analytic review of the social psychological literature. Psychological Bulletin, 100(1), 283-308.

Eagly, A. H., \& Wood, W. (2016). Social role theory of sex differences. In M. Baker (Ed.), The Wiley Blackwell encyclopedia of gender and sexuality studies (pp. 1-3). Hoboken, NJ: John Wiley \& Sons.

Eggers, A., Vivyan, N., \& Wagner, M. (2018). Corruption, accountability, and gender: Do female politicians face higher standards in public life? The Journal of Politics, 80(1), 321-326.

Ennser-Jedenastik, L. (2017). How women's political representation affects spending on family benefits. Journal of Social Policy, 46(3), 563-581.

Esarey, J., \& Schwindt-Bayer, L. A. (2018). Women's representation, accountability and corruption in democracies. British Journal of Political Science, 48(3), 659-690.

Esarey, J., \& Schwindt-Bayer, L. A. (2019). Estimating causal relationships between women's representation in government and corruption. Comparative Political Studies, 52(11), 1713-1741.

Escobar-Lemmon, M., \& Taylor-Robinson, M. (2009). Getting to the top: Career paths of women in Latin American cabinets. Political Research Quarterly, 62(4), 685-699.

Fišar, M., Kubák, M., Špalek, J., \& Tremewan, J. (2016). Gender differences in beliefs and actions in a framed corruption experiment. Journal of Behavioral and Experimental Economics, 63(1), 69-82.

Fisman, R., \& Gatti, R. (2002). Decentralization and corruption: Evidence across countries. Journal of Public Economics, 83(3), 325-345.

Goertzel, T. (1983). The gender gap: Sex, family income and political opinions in the early 1980s. Journal of Political and Military Sociology, 11(1), 209-222.

Goetz, A. (2007). Political cleaners: Women as the new anti-corruption force? Development and Change, 38(1), 87-105.

Heath, R., Schwindt-Bayer, L., \& Taylor-Robinson, M. (2005). Women on the sidelines: Women's representation on committees in Latin American legislatures. American Journal of Political Science, 49(2), 420-436.

Heidenheimer, A. J., \& Johnston, M. (2002). Political corruption: Concepts and contexts. Piscataway, NJ: Transaction Publishers.

Hernandez, T., \& McGee, R. W. (2012). Ethical attitudes toward taking a bribe: A study of four European countries. Euro Asia Journal of Management, 41, 3-28.

Heywood, P. M. (2017). Rethinking corruption: Hocuspocus, locus and focus. Slavonic \& East European Review, 95(1), 21-48.

Holmberg, S. (2009). Perceptions of corruption in mass publics (QoG Working Paper Series, 24). Gothenburg: The Quality of Government Institute.

Jha, C., \& Sarangi, S. (2018). Women and corruption: What positions must they hold to make a difference? Journal of Economic Behavior \& Organization, 151(1), 219-233.

Justesen, M. K., \& Bjørnskov, C. (2014). Exploiting the poor: Bureaucratic corruption and poverty in Africa. World Development, 58(June), 106-115.

Manzetti, L., \& Wilson, C. J. (2006). Corruption, economic satisfaction, and confidence in government: Evidence from Argentina. The Latin Americanist, 49(2), 131-139.

Mauro, P. (1995). Corruption and growth. The Quarterly Journal of Economics, 110(3), 681-712.

Melgar, N., Rossi, M., \& Smith, T. W. (2010). The perception of corruption. International Journal of Public Opinion Research, 22(1), 120-131.

Neudorfer, N. (2016). Gender and graft: A political economy argument about the influence of working women on political corruption. Journal of Women, Politics and Policy, 37(2), 190-216.

Razafindrakoto, M., \& Roubaud, F. (2010). Are international databases on corruption reliable? A comparison of expert opinion surveys and household surveys in sub-Saharan Africa. World Development, 38(8), 1057-1069.

Schwindt-Bayer, L. A. (2010). Political power and women's representation in Latin America. Oxford: Oxford University Press.

Schwindt-Bayer, L. A., \& Mishler, W. (2005). An integrated model of women's representation. Journal of Politics, 67(2), 407-428. 
Smith, A. R. (2014). Cities where women rule: Female political incorporation and the allocation of community development block grant funding. Politics and Gender, 10(3), 313-340.

Stensöta, H., Wängnerud, L., \& Svensson, R. (2015). Gender and corruption. The mediating power of institutional logics. Governance, 28(4), 475-496.

Stensöta, H., \& Wängnerud, L. (Eds.). (2018). Gender and corruption: Historical roots and new avenues for research. Berlin: Springer.

Stockemer, D., \& Sundström, A. (2019). Corruption and women in cabinets: Informal barriers to recruitment in the executive. Governance, 32(1), 83-102. https:// doi.org/10.1111/gove.12352

Sundström, A. (2013). Women's local political representation within 30 European countries (QoG Working Paper Series, 18). Gothenburg: The Quality of Government Institute.

Sundström, A., \& Wängnerud, L. (2016). Corruption as an obstacle to women's political representation: Evidence from local councils in 18 European countries. Party Politics, 22(3), 354-369.

Swamy, A., Knack, S., Lee, Y., \& Azfar, O. (2001). Gender and corruption. Journal of Development Economics, 64(1), 25-55.

Torgler, B., \& Valev, N. T. (2010). Gender and public attitudes toward corruption and tax evasion. Contemporary Economic Policy, 28(4), 554-568.

Treisman, D. (2007). What have we learned about the causes of corruption from ten years of cross-national empirical research? Annual Review of Political Science, 10(1), 211-244.

Truex, R. (2011). Corruption, attitudes, and education: Survey evidence from Nepal. World Development, 39(7), 1133-1142.

Tverdova, Y. V. (2011). See no evil: Heterogeneity in public perceptions of corruption. Canadian Journal of Political Science/Revue Canadienne de Science Politique, 44(1), 1-25.

Watson, J., \& McNaughton, M. (2007). Gender differences in risk aversion and expected retirement benefits. Financial Analysts Journal, 63(4), 52-62.

Żemojtel-Piotrowska, M., Marganski, A., Baran, T., \& Piotrowski, J. (2017). Corruption and sexual scandal: The importance of politician gender. Anales de Psicología/Annals of Psychology, 33(1), 133-141.

\section{About the Authors}

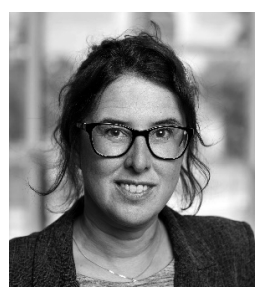

Monika Bauhr is an Associate Professor at the Department of Political Science, University of Gothenburg, and a Research Fellow at the Quality of Government Institute. She is currently a Visiting Scholar at the Minda de Gunzburg Center for European Studies, Harvard University. Her research is mainly concerned with the link between democracy and corruption, foreign aid, gender and corruption and EU political behaviour.

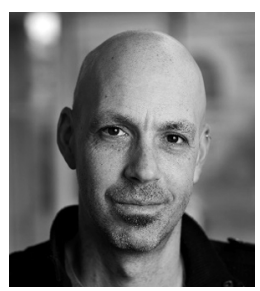

Nicholas Charron is an Associate Professor in the Department of Political Science at the University of Gothenburg, Sweden, and a Research Fellow at the Quality of Government Institute, from the same university. His work has mainly focused on the causes and consequences of state capacity and corruption, multi-level governance within the EU, public opinion and electoral behaviour. He is the author and co-creator of the European Quality of Government Index, which measures quality of government at the sub-nationally for over 200 regions in Europe. 